\title{
Effects of FSH on testicular mRNA transcript levels in the hypogonadal mouse
}

\author{
M H Abel, D Baban, S Lee, H M Charlton and P J O'Shaughnessy' \\ Department of Physiology, Anatomy and Genetics, University of Oxford, Le Gros Clarke Building, Oxford OX1 3QX, UK \\ ${ }^{1}$ Institute of Comparative Medicine, University of Glasgow Veterinary School, Bearsden Road, Glasgow G61 1QH, UK \\ (Correspondence should be addressed to P J O’Shaughnessy; Email: p.j.oshaughnessy @ vet.gla.ac.uk)
}

(D Baban is now at Genomics Group, The Wellcome Trust Centre for Human Genetics, University of Oxford, Roosevelt Drive, Oxford OX3 7BN, UK)

\begin{abstract}
FSH acts through the Sertoli cell to ensure normal testicular development and function. To identify transcriptional mechanisms through which FSH acts in the testis, we have treated gonadotrophin-deficient hypogonadal ( $h p g$ ) mice with recombinant FSH and measured changes in testicular transcript levels using microarrays and real-time PCR 12, 24 and $72 \mathrm{~h}$ after the start of treatment. Approximately 400 transcripts were significantly altered at each time point by FSH treatment. At $12 \mathrm{~h}$, there was a clear increase in the levels of a number of known Sertoli cell transcripts (e.g. Fabp5, Lgals1, Tesc, Scara5, Aqp5). Additionally, levels of Leydig cell transcripts were also markedly increased (e.g. Ren1, Cyp17a1, Akr1b7, Star, Nr4a1). This was associated with a small but significant rise in testosterone at 24 and $72 \mathrm{~h}$. At $24 \mathrm{~h}$, androgen-dependent Sertoli cell transcripts were up-regulated (e.g. Rhox5, Drd4, Spin/w1, Tubb3 and Tsx) and this trend continued up to $72 \mathrm{~h}$. By contrast with the somatic cells, only five germ cell transcripts (Dkkl1, Hdc, Pou5f1, Zfp541 and $1700021 \mathrm{KO} 2 \mathrm{Rik}$ ) were altered by FSH within the time-course of the experiment. Analysis of canonical pathways showed that FSH induced a general decline in transcripts related to formation and regulation of tight junctions. Results show that FSH acts directly and indirectly to induce rapid changes in Sertoli cell and Leydig cell transcript levels in the $h p g$ mouse but that effects on germ cell development must occur over a longer time-span.
\end{abstract}

Journal of Molecular Endocrinology (2009) 42, 291-303

\section{Introduction}

Postnatal testicular growth, spermatogenesis and fertility are dependent upon the pituitary gonadotrophins FSH and LH. LH acts directly on Leydig cells to stimulate androgen production, while androgens and FSH stimulate spermatogenesis through direct action on the Sertoli cells (McLachlan et al. 2002). The role of gonadotrophins is clearly seen in the hypogonadal ( $h p g$ ) mouse that lacks GnRH (Mason et al. 1986) and, consequently, has undetectable circulating levels of LH and FSH (Cattanach et al. 1977). The gonads of the $h p g$ mouse remain in a pre-pubertal state throughout life, with spermatogenesis blocked at early meiosis (Cattanach et al. 1977, Myers et al. 2005) although treatment with exogenous gonadotrophins or androgens will increase testicular growth and restore germ cell development (Charlton et al. 1983, Singh \& Handelsman 1996a,b, Haywood et al. 2003). In recent years, generation of mice lacking individual hormones or hormone receptors has allowed us to investigate more clearly the roles played by LH, FSH and androgen in the regulation of testicular function. In particular, study of mice lacking androgen receptors (AR) in the Sertoli cells (SCARKO
(De Gendt et al. 2004)) has shown that androgens are essential for spermatocyte progression through meiosis. By contrast, mice lacking FSH (FSHßKO (Kumar et al. 1997)) or the FSH receptor (FSHRKO; Dierich et al. 1998, Abel et al. 2000) are fertile with all stages of spermatogenesis present. Nevertheless, in FSHRKO and FSHBKO mice there is a reduction in sperm number and quality (Krishnamurthy et al. 2001, Wreford et al. 2001) suggesting that FSH action optimises spermatogenesis. In addition, comparison of SCARKO mice with mice lacking both FSHR and AR on the Sertoli cells has shown that FSH acts to increase Sertoli cell number, total germ cell number and the number of germ cells associated with each Sertoli cell (Abel $e t$ al. 2008). This is achieved by an increase in the number of spermatogonia and enhanced entry of these cells into meiosis (Abel et al. 2008).

Previous studies have identified a number of Sertoli cell products or mRNA transcripts that are FSHsensitive including, for example, inhibin, AR, transferrin, doublesex and mab-3 related transcription factor1 (DMRT), androgen-binding protein and inducible cAMP early repressor (Morris et al. 1988, Verhoeven \& Cailleau 1988, Skinner et al. 1989, Monaco et al. 1995, Chen \& Heckert 2001). In addition, an earlier study has 
used arrays to examine the short-term effects (up to $24 \mathrm{~h}$ ) of a single injection of FSH on testicular gene expression in vivo (Sadate-Ngatchou et al. 2004). From these studies, we can now identify a number of transcripts acutely regulated by FSH but we continue to lack a clear understanding of how FSH acts to regulate testicular development and function over the longer term. To address this issue, we have carried out a comprehensive review of the effects of more prolonged FSH treatment (multiple injections up to $72 \mathrm{~h}$ ) on transcript levels in the testis of the $h p g$ mouse.

\section{Materials and methods}

\section{Animals and treatments}

$h p g$ mice from the original colony first identified at the MRC Laboratories, Harwell, Oxford (Cattanach et al. 1977) were bred at Oxford. The $h p g$ mutation was identified by PCR analysis of tail DNA as previously reported (Lang 1995). All procedures were carried out in accordance with the UK Animals (Scientific Procedures) Act 1986 and with the approval of a local ethical review committee.

Male $h p g$ mice, 10 weeks of age and in group sizes of 3-4, were injected subcutaneously with 8 IU recombinant human FSH (rhFSH) (Serono Ltd) in $0.2 \mathrm{ml}$ PBS (PBS, pH 7.4, Sigma Aldrich) at the start of the experiment and every $12 \mathrm{~h}$ thereafter for 12,24 or $72 \mathrm{~h}$. This dose of recombinant hormone had previously been shown to induce a significant increase in testis weight in $h p g$ mice when given for 1 week (Abel and Charlton unpublished). Mice were killed $1 \mathrm{~h}$ after the last injection, testes removed, snap frozen in liquid nitrogen and stored at $-70^{\circ} \mathrm{C}$.

\section{Testicular histology}

Three $h p g$ mice treated as above were killed at each time point. The testes were weighed and one testis from each animal was fixed in $1 \%$ glutaraldehyde, $4 \%$ paraformaldehyde, in phosphate buffer, $0 \cdot 1 \mathrm{M}$, pH $7 \cdot 2$ for $24 \mathrm{~h}$ at $4{ }^{\circ} \mathrm{C}$, and embedded in araldite. Semi-thin, $1 \mu \mathrm{m}$ sections were cut and stained with toluidine blue.

\section{DNA microarray}

Three or four animals from FSH-treated or control $h p g$ groups were killed at each time point and the RNA from testes of individual animals extracted on RNeasy columns (Qiagen). RNA was quantified using a NanoDrop ND-1000 (NanoDrop, Wilmington, DE, USA) and RNA quality was checked using the Agilent bioanalyzer 2100 (Agilent, Santa Clara, CA, USA). Samples of total RNA ( $8 \mu \mathrm{g})$ from individual animals were reverse transcribed and then in vitro transcribed and hybridised to mouse MOE430A arrays (Affymetrix, Santa Clara, CA, USA) ( $n=3$ or 4 for each group) according to the GeneChip expression technical manual (Affymetrix) as previously reported (Baban \& Davies 2008). All the experiments were designed and information compiled in compliance with MIAME guide lines. Gene transcript levels were determined from data image files using algorithms in Gene Chip Operating Software (GCOS1.2, Affymetrix).

The array data were generated in two batches. In the first experiment control, 12 and $72 \mathrm{~h} \mathrm{FSH} \mathrm{groups} \mathrm{were}$ extracted and hybridised to the arrays and in a subsequent experiment control and $24 \mathrm{~h}$ FSH groups were processed in the same way. Each treatment group was analysed against its own control. Differentially expressed genes were identified using the Welch $t$-test, variance not assumed equal, $P<0 \cdot 05$. Analysis of canonical pathways was carried out using Ingenuity Pathways Analysis (www.ingenuity.com).

The data discussed in this publication have been deposited in NCBIs Gene Expression Omnibus (GEO, http://www.ncbi.nlm.nih.gov/geo/) and are accessible through GEO Series accession GSE8924.

\section{Real-time PCR}

Total RNA was extracted from individual testes of control or FSH-treated $h p g$ mice using Trizol (Life technologies) and residual genomic DNA was removed by DNAse treatment (DNA-free, Ambion Inc., Austin, TX, USA, supplied by AMS Biotechnology, Abingdon, UK). RNA ( $1 \mu \mathrm{g})$ was reverse transcribed using random hexamers (Ambion) and Moloney murine leukaemia virus reverse transcriptase (Life Technologies) as previously described (Hirst et al. 2004).

Quantitative real-time PCR was used to confirm changes in selected mRNA transcripts identified from the microarray analysis or to examine other transcripts of potential interest. The real-time PCR used either the Taqman (Inha, Inhba, Inhbb and Hdc) or the SYBR green (all other transcripts) method in a 96-well plate format. For Taqman, Universal Taqman master mix, and optimised primer and probe sets were purchased from Applied Biosystems (Warrington, UK) and used according to the manufacturer's recommendations in a $25 \mu \mathrm{l}$ volume. For SYBR green, each reaction contained $5 \mu \mathrm{l}$ $2 \times$ SYBR mastermix (Stratagene, Amsterdam, Netherlands), primer (100 $\mathrm{nM})$ and template in a total volume of $10 \mu \mathrm{l}$. The thermal profile used for amplification was $95^{\circ} \mathrm{C}$ for $8 \mathrm{~min}$ followed by 40 cycles of $95^{\circ} \mathrm{C}$ for $25 \mathrm{~s}$, $63{ }^{\circ} \mathrm{C}$ for $25 \mathrm{~s}$ and $72^{\circ} \mathrm{C}$ for $30 \mathrm{~s}$. At the end of the amplification phase a melting curve analysis was carried out on the products formed. All primers were designed by Primer Express 2.0 (Applied Biosystems) using parameters previously described (Czechowski et al. 2004). 
No-RT controls for each sample were screened to check for the presence of residual genomic DNA. The primers and probes used for real-time SYBR PCR are shown in Supplementary Table 1, see supplementary data in the online version of the Journal of Molecular Endocrinology at http://jme.endocrinology-journals.org/ content/vol42/issue4/. Different animals were used to provide RNA for real-time PCR and microarray studies.

\section{Hormone assay}

In a separate study adult $h p g$ mice were treated with rhFSH as above and intratesticular levels of testosterone measured by RIA following ethanol extraction as previously described (O'Shaughnessy \& Sheffield 1990). The limit of detection of the assay was $25 \mathrm{fmol} /$ testis.

\section{Statistical analysis}

With the exception of the array studies described above, the effects of FSH treatment were analysed initially by single-factor ANOVA followed by post hoc analysis using Fisher's test.

\section{Results}

\section{Testicular weight and histology after rhFSH treatment}

There was a significant increase in testis weight within $12 \mathrm{~h}$ of the start of FSH treatment and weight continued to increase up to $24 \mathrm{~h}$ (Fig. 1A). This weight increase was accompanied by an apparent increase in tubular diameter with clear formation of a tubular lumen (Fig. 1B). On the semi-thin light micrographs, there was also an apparent increase in vacuolation of the Sertoli cell cytoplasm by $24 \mathrm{~h}$ which became more marked by $72 \mathrm{~h}$ (Fig. 1B). This was confirmed on electron micrographs with several small vacuoles apparent within the cytoplasm at $24 \mathrm{~h}$ and larger vacuoles present at $72 \mathrm{~h}$ (Fig. 1C). There was no clear advancement of spermatogenesis within the timescale of the experiment.

\section{Hormone levels}

Intratesticular testosterone levels were undetectable in control $h p g$ mice $(<25 \mathrm{fmol} /$ testis $(<12 \mathrm{fmol} / \mathrm{mg}$ tissue), $n=8$ ) and increased to low but consistently detectable levels $24 \mathrm{~h}$ after the start of treatment with FSH $\quad(65 \cdot 0 \pm 12 \cdot 4 \mathrm{fmol} /$ testis $\quad(19 \cdot 1 \pm 3 \cdot 6 \mathrm{fmol} / \mathrm{mg})$, $n=4)$ and remained detectable up to $72 \mathrm{~h}(76 \cdot 2 \pm$ $45 \cdot 0 \mathrm{fmol} /$ testis $(19 \cdot 5 \pm 11 \cdot 5 \mathrm{fmol} / \mathrm{mg}), n=4)$.
A
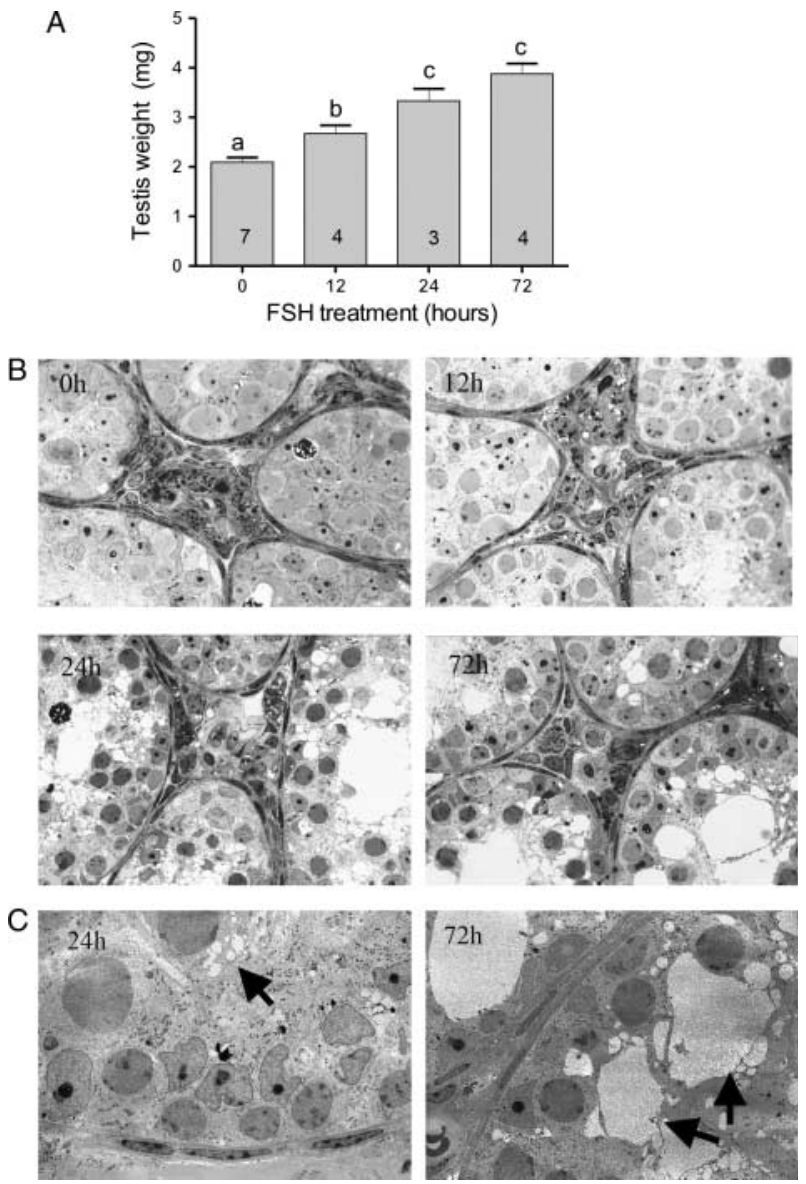

Figure 1 Effect of rhFSH on testis weight and morphology in hpg mice. A) Testis weights of control adult hpg mice and mice treated every $12 \mathrm{~h}$ with FSH ( $n$ for each group is shown in the histogram). B) Semi-thin sections of testes from control adult $h p g$ mice and mice treated with FSH for 12, 24 and $72 \mathrm{~h}$. Note the appearance of vacuoles within the cytoplasm of the Sertoli cell at 24 and $72 \mathrm{~h}$ post-treatment. C) Electron micrographs at 24 and $72 \mathrm{~h}$, arrows indicate the progression from multiple small vacuoles to fewer large vacuoles.

\section{Microarray data}

Analysis of the array data showed that there were 182, 164 and 203 transcripts significantly (>2-fold) increased in the $h p g$ testis 12,24 and $72 \mathrm{~h}$ after the start of FSH treatment and 162, 411 and 215 significantly decreased at the same times. Transcripts with the highest fold changes in expression at each time during treatment are listed in Table 1 and the complete list of significantly altered transcripts ( $>2$-fold) is shown in Supplementary Table 2, see supplementary data in the online version of the Journal of Molecular Endocrinology at http://jme.endocrinology-journals. $\mathrm{org} /$ content/vol42/issue $4 /$. At $12 \mathrm{~h}$ after the start of FSH treatment, there was a clear increase in the levels of a number of transcripts known to be expressed in the Sertoli cells (e.g. Fabp5, Lgals1, Tesc and Scara5; 
Table 1 Effects of FSH treatment on testicular transcript levels - highest-regulated transcripts from microarray studies ${ }^{a}$

Gene symbol
Gene title
Fold Gene change symbol
Gene title

\section{Fold} change

Transcripts up-regulated $12 \mathrm{~h}$ after start of treatment

$18 \cdot 2$

$13 \cdot 3$

$12 \cdot 1$

$11 \cdot 0$

6.6

6.5

6.3

$6 \cdot 0$

5.9

$5 \cdot 7$

$5 \cdot 2$

$4 \cdot 6$

$4 \cdot 6$

$4 \cdot 6$

$4 \cdot 6$

$4 \cdot 4$

$4 \cdot 4$

$4 \cdot 2$

$4 \cdot 1$

$4 \cdot 0$

3.9

3.8

$3 \cdot 8$

3.7

3.7

3.7

$3 \cdot 7$

$3 \cdot 6$

3.6

Renin 1 structural

Dermokine

Aquaporin 5

Wnt inhibitory factor 1

Fabp5

Tubb3

Cyp17a1

Akr1b7

Lgals1

Col4a1

Pappa

Star

Ldlr

Tesc

Rps6ka2

Scara5

Hgsnat

Hs3st1

Syne1

Slc38a5

Gpd1

Dos

Svs5

Bhmt

D9Ertd280e

Tnfrsf12a

1200016-

E24Rik

Nr4a1

Dkk3

Tubulin, $\beta 3$

Procollagen, type IV, $\alpha 1$

Tescalcin

Heparan $\mathrm{N}$-acetyltransferase

Synaptic nuclear envelope 1

Downstream of Stk11

Chr 9, ERATO Doi 280

RIKEN cDNA 1200016E24

group A1

Dickkopf homolog 3

Cytochrome P450, family 51
Transcripts up-regulated $24 \mathrm{~h}$ after start of treatment

28.8 Lin7c

$18 \cdot 0$

$13 \cdot 6$

$11 \cdot 0$

$10 \cdot 1$

$9 \cdot 4$

$8 \cdot 7$

$7 \cdot 9$

$7 \cdot 4$

$7 \cdot 0$

$6 \cdot 3$

$5 \cdot 5$

$5 \cdot 0$

$4 \cdot 6$

4.5

$4 \cdot 2$

$4 \cdot 2$

$4 \cdot 2$

$4 \cdot 1$

$4 \cdot 0$

$4 \cdot 0$

$4 \cdot 0$

$4 \cdot 0$

$3 \cdot 8$

Cyp17a1
Cyp11a1
Fabp5
Rhox5
Star
Slc38a5
Aqp5
Tubb3
Drd4
Tesc
Lgals1
Spinlw1
Osr1
Fads2
Pappa
Scara5
Pscdbp
Plac8
Gpt2
Rps6ka2
Gpd1
Hdc
Igf1

Reproductive homeobox 5

Aquaporin 5

Tubulin, $\beta 3$

Dopamine receptor 4

Tescalcin

Eppin

Odd-skipped related 1

Fatty acid desaturase 2

Scavenger receptor class A5

Placenta-specific 8

Histidine decarboxylase

Insulin-like growth factor 1
Fatty acid binding protein 5 , epidermal

Cytochrome P450, family 17 a 1

Aldo-keto reductase family $1 \mathrm{~B} 7$

Lectin, galactose binding, soluble 1

Pregnancy-associated plasma protein A

Steroidogenic acute regulatory protein

Low density lipoprotein receptor

Ribosomal protein S6 kinase 2

Scavenger receptor class A 5

Heparan sulphate 3 -O-sulphotransferase 1

Solute carrier family 38 , member 5

Glycerol-3-phosphate dehydrogenase 1

Seminal vesicle secretory protein 5

Betaine-homocysteine methyltransferase

Tumour necrosis factor receptor $12 \mathrm{a}$

Nuclear receptor subfamily 4 ,

Lin-7 homolog C (C. elegans)

Cytochrome P450, family 17a1

Cytochrome P450, family 11a1

Fatty acid binding protein 5 , epidermal

Steroidogenic acute regulatory protein

Solute carrier family 38 , member 5

Lectin, galactose binding, soluble 1

Pregnancy-associated plasma protein A

Pleckstrin homology binding protein

Glutamic pyruvate transaminase 2

Ribosomal protein S6 kinase 2

Glycerol-3-phosphate dehydrogenase 1
Transcripts down-regulated $12 \mathrm{~h}$ after start of treatment

7.27 Myh8 Myosin, heavy polypeptide 8

6.65 Rin2 Ras and Rab interactor 2

5.03 Pdgfc Platelet-derived growth factor $\mathrm{C}$

Transcribed locus ${ }^{b}$

4.53 Bcan Brevican

4.46 Rgs11 Regulator of G-protein signalling 11

4.45 Tmem37 Transmembrane protein 37

4.43 Fhod3 Formin homology 2 domain containing 3

4.38 Derl3 Der1-like domain family, member 3

4.01 Ddit4I DNA-damage-inducible transcript 4-like

3.98 BC013672 cDNA sequence BC013672

3.97 Scin Scinderin

3.96 Ddit4I DNA-damage-inducible transcript 4-like

3.89 Cabc1 Chaperone, ABC1 complex-like

3.86 Krt20 Keratin 20

3.74 Tmem140 Transmembrane protein 140

3.71 Dbp D site albumin promoter binding protein

3.71 Rnasel Ribonuclease $L$

3.70 Spsb1 splA receptor domain and SOCS box 1

3.67 Tnni3 Troponin I, cardiac

3.65 Cdo1 Cysteine dioxygenase 1, cytosolic

3.57 Stard8

3.55 Slc40a1

3.52 Hdac5

3.32 Dbp

3.23 Chdh

3.23 8030411-

F24Rik

3.23 Per3

START domain containing 8

Solute carrier family 40 , member 1

Histone deacetylase 5

D site albumin promoter binding protein

Choline dehydrogenase

RIKEN cDNA 8030411 F24 gene

3.22 Ctnna2

3.19 Trim47

Period homolog 3 (Drosophila)

Catenin, $\alpha 2$

Tripartite motif protein 47

Transcripts down-regulated $24 \mathrm{~h}$ after start of treatment

9.9 Ddit4I

DNA-damage-inducible transcript

4-like

9.9 Rin2

9.1 Slc40a1

8.0 Rgs11

7.6 Igfbp3

7.4 Myh6

7.2 Apbb2

6.7 Rassf5

6.3 Tmem37

6.3 Chdh

6.2 Itga9

6.2 Thbd

5.9 Fcgr2b

5.8 Trim47

5.7 Spsb1

5.6 Ddit4l

5.5 Vnn1

5.5 Fcgr2b

5.4 Ptprd

5.4 Nkx3-1

5.3 Fcgr2b

5.1 Ctgf

5.0 H19

5.0 Pdgfc
Ras and Rab interactor 2

Solute carrier family 40, member 1

Regulator of G-protein signalling 11

Insulin-like growth factor binding protein 3

Myosin, heavy polypeptide $6 \alpha$

Amyloid precursor protein-binding B2

Ras association domain family 5

Transmembrane protein 37

Choline dehydrogenase

Integrin $\alpha 9$

Thrombomodulin

Fc receptor, IgG, low affinity IIb

Tripartite motif protein 47

splA receptor domain and SOCS box 1

DNA-damage-inducible transcript 4-like

Vanin 1

Fc receptor, IgG, low affinity Ilb

Protein tyrosine phosphatase, receptor D

NK-3 transcription factor, locus 1

Fc receptor, IgG, low affinity IIb

Connective tissue growth factor

H19 fetal liver mRNA

Platelet-derived growth factor $\mathrm{C}$

(continued) 
Table 1 Continued

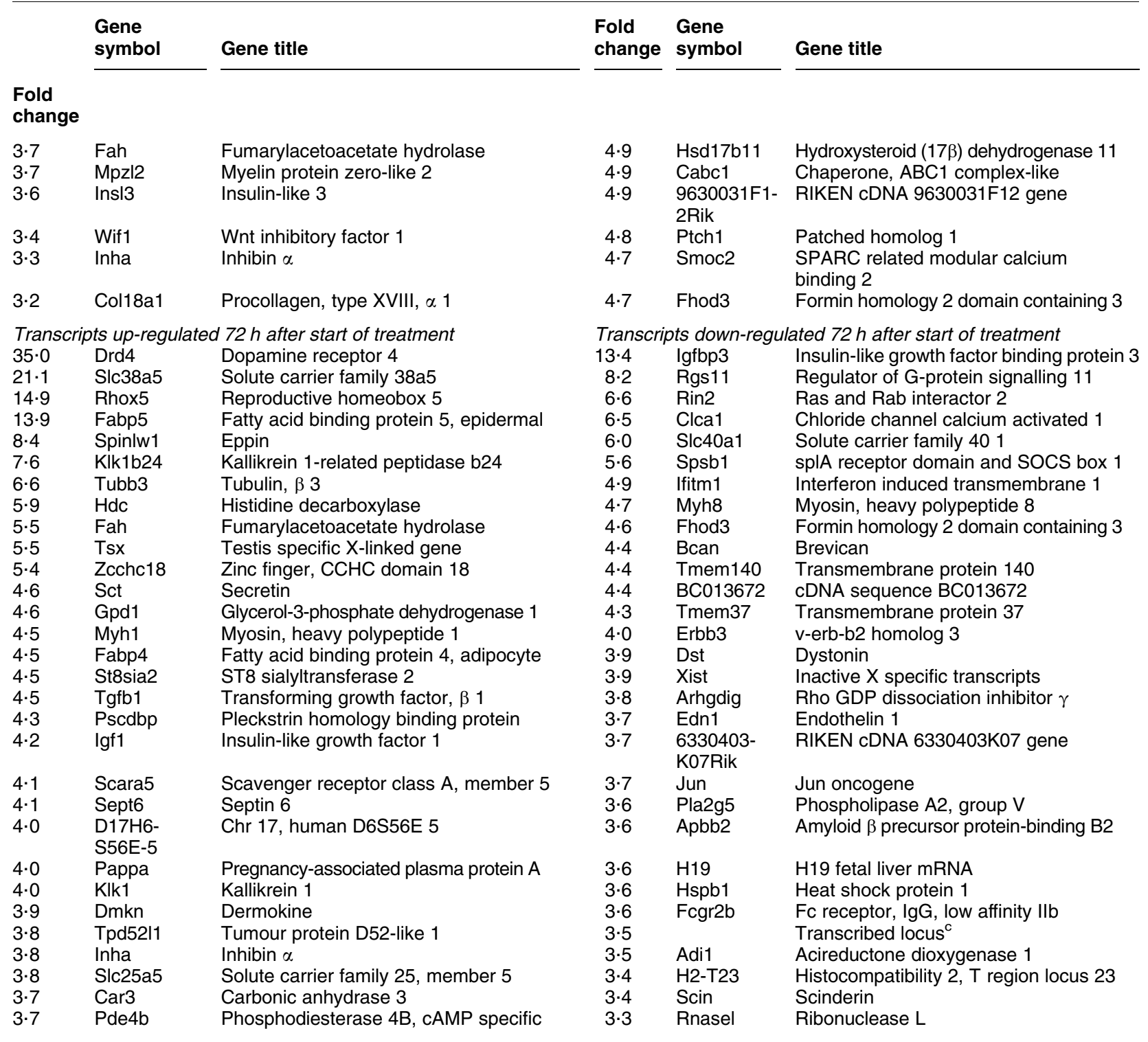

${ }^{a}$ If a transcript is represented more than once on the array only the highest fold change is shown in this table. Supplementary Table 2 shows the complete significant dataset.

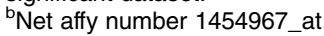

${ }^{c}$ Net affy number 1436092_at.

Kingma et al. 1998, Perera et al. 2001, Dettin et al. 2003, Jiang et al. 2006) and, perhaps surprisingly, in the Leydig cells (e.g. Ren1, Cyp17a1, Akr1b7, Star, Ldlr and Nr4a1; Deschepper et al. 1986, Le Goascogne et al. 1991, Song et al. 2001, Baron et al. 2003; Table 1). By $24 \mathrm{~h}$ after the start of FSH treatment, androgen-dependent Sertoli cell transcripts appeared in the list of up-regulated transcripts (e.g. Rhox5, Drd4, Spinlw1 and Tubb3; Lindsey \& Wilkinson 1996, Cunningham et al. 1998, Denolet et al. 2006, O'Shaughnessy et al. 2007) and this trend became more marked by $72 \mathrm{~h}$. By contrast with the somatic cells, very few germ cell genes appear on the lists of significantly regulated transcripts. Only $H d c$ (increased $4 \cdot 0$ - and $5 \cdot 9$-fold at 24 and $72 \mathrm{~h}$ respectively; Safina et al. 2002) and 1700021K02Rik (Spatial) (increased $3 \cdot 1$-fold at $72 \mathrm{~h}$ ) (Irla et al. 2003) were significantly altered by FSH within the time-span of these studies (Table 1 and Supplementary Table 2).

Few of the transcripts down-regulated following FSH treatment have been localised in the testis with the 
exception of $\operatorname{Ig} f b p 3$ which has been shown to be of Sertoli cell origin (Smith et al. 1990). In order to identify more of the differentially expressed transcripts on the arrays, which may be of a Sertoli cell origin, up- and downregulated transcripts were compared with those identified as being of likely Sertoli cell origin by Chalmel $\mathrm{et} \mathrm{al}$. (2007) using a cell isolation, GeneChip and clustering approach (Supplementary Table 2A and B). A degree of caution is required as some known Sertoli cell transcripts (e.g. Rhox5) are missing from the list generated by Chalmel et al. (2007) probably due to Chip sensitivity or the subsequent filtering process. Nevertheless, of the transcripts up-regulated at $12 \mathrm{~h}, 44 \%$ matched to the data from Chalmel et al. (2007). Interestingly, this number declined to $35 \%$ at $24 \mathrm{~h}$ and $27 \%$ at $72 \mathrm{~h}$ after the start of FSH treatment (Supplementary Table 2A). The number of down-regulated transcripts that matched the Sertoli cell list was 27, 21 and $28 \%$ at 12, 24 and $72 \mathrm{~h}$ respectively (Supplementary Table 2B).

\section{Real-time PCR}

\section{Leydig cell genes}

To confirm results from the array studies, real-time PCR was used to measure the effect of FSH treatment on testicular expression of selected transcripts which are known to be expressed exclusively in the Leydig cells (O'Shaughnessy et al. 2002). Eight mRNA species were tested which had shown an increase in transcript levels on the arrays after FSH (Star, Cyp17a1, Hsd17b3, Akr1b7, Lhr, Cyp11a1, Insl3 and Ren 1) (Fig. 2A). Results from the real-time PCR studies confirmed that seven of these transcripts are regulated by FSH in the $h p g$ testis, although no change in $L h r$ was seen. Two other Leydig cell mRNA species (Hsd3b6 and Sult1e1) that had not shown any response to FSH on the arrays were also tested by real-time PCR (Fig. 2A). Levels of Hsd3b6 did not show a response to FSH but there was a significant, if variable, increase in Sult1e1 after $72 \mathrm{~h}$.

\section{Androgen-dependent genes}

The array studies showed clearly that a number of androgen-dependent Sertoli cell transcripts were altered after FSH treatment. Real-time PCR was used to confirm changes in selected transcripts (Rhox 5 , Tsx, Drd4, Spinlw1 (Eppin) and Igfbp3) shown previously to be androgen-regulated (Lindsey \& Wilkinson 1996, Denolet et al. 2006, O'Shaughnessy et al. 2007; Fig. 2B). In agreement with results from the array studies four transcripts (Rhox5, Tsx, Drd4 and Spinlw1) showed increased expression 24-72 h after FSH treatment while one transcript $(\operatorname{Ig} f b p 3)$ showed a significant decrease in expression (Fig. 2B).

\section{Sertoli cell genes}

In addition to androgen-dependent Sertoli cell genes described above, 16 other Sertoli cell transcripts were measured by real-time PCR following FSH treatment of adult $h p g$ mice (Fig. 3). Of these transcripts, seven had shown significantly increased expression on the arrays (Tesc, Lgals1, Aqp5, Dhh, Pappa, Wnt4 and Shbg), six had not shown any significant change (Trf, Wt1, Amh, Spata2, Tjp1 and $G d n f)$, two had shown a significant decrease (Fshrand Rgs 11) after FSH treatment and one transcript (Defb19) was not on the array. Results from real-time studies confirmed increased transcript levels for six out of the seven mRNA species identified on the array (the exception was $S h b g$ ) and for the one transcript (Defb19) not on the array (Fig. 3A). Both transcripts decreased on the arrays after FSH treatment also showed a significant decrease by real-time PCR (Fig. 3A). Interestingly, however, the real-time PCR data showed there was a significant increase in levels of three out of the six transcripts that were not significantly changed on the arrays (Trf, Wt1 and Amh; Fig. 3A). Two of these transcripts (Trfand $A m h$ ) had shown a greater than twofold increase on the arrays but had not reached significance. Differences between results from real-time PCR and arrays may be a matter of sensitivity and variability of the two techniques or may be due to the choice of primers, away from the $3^{\prime}$ region targeted by these arrays.

The inhibin subunits are expressed in a number of cell types in the testis (Barakat et al. 2008) although it might be expected that initial responsiveness to FSH would be predominantly localised in the Sertoli cells. On the arrays, both Inha and Inhbb were significantly increased by FSH (Table 1 and Supplementary Table 2) while there was no effect on Inhba. Results from the realtime PCR studies reflected the same pattern of results (Fig. 3B).

\section{Germ cell genes}

The number of known germ cell transcripts on the array affected by FSH, within the time-span of the study, was not high. This was, therefore, investigated further using real-time PCR. Expression of nine germ cell transcripts known to be expressed predominantly in spermatogonia (Stra8, Pou5f1, Dkkl1 and Spo11), spermatocytes (Mybl1, Zfp541) or spermatids (1700021K02Rik, Hdc and Tp1) was measured following FSH treatment (Fig. 4). Expression levels of Stra8, Spo11, Mybl1 and Tp1 were unaffected by treatment but there was a transient increase in Pou $5 f 1$ at $12 \mathrm{~h}$ while $D k k l 1$ and $Z f p 541$ were significantly increased at $72 \mathrm{~h}$. Expression of Hdc and 1700021K02Rik (shown previously to be increased on the array) was increased at all times after treatment. 

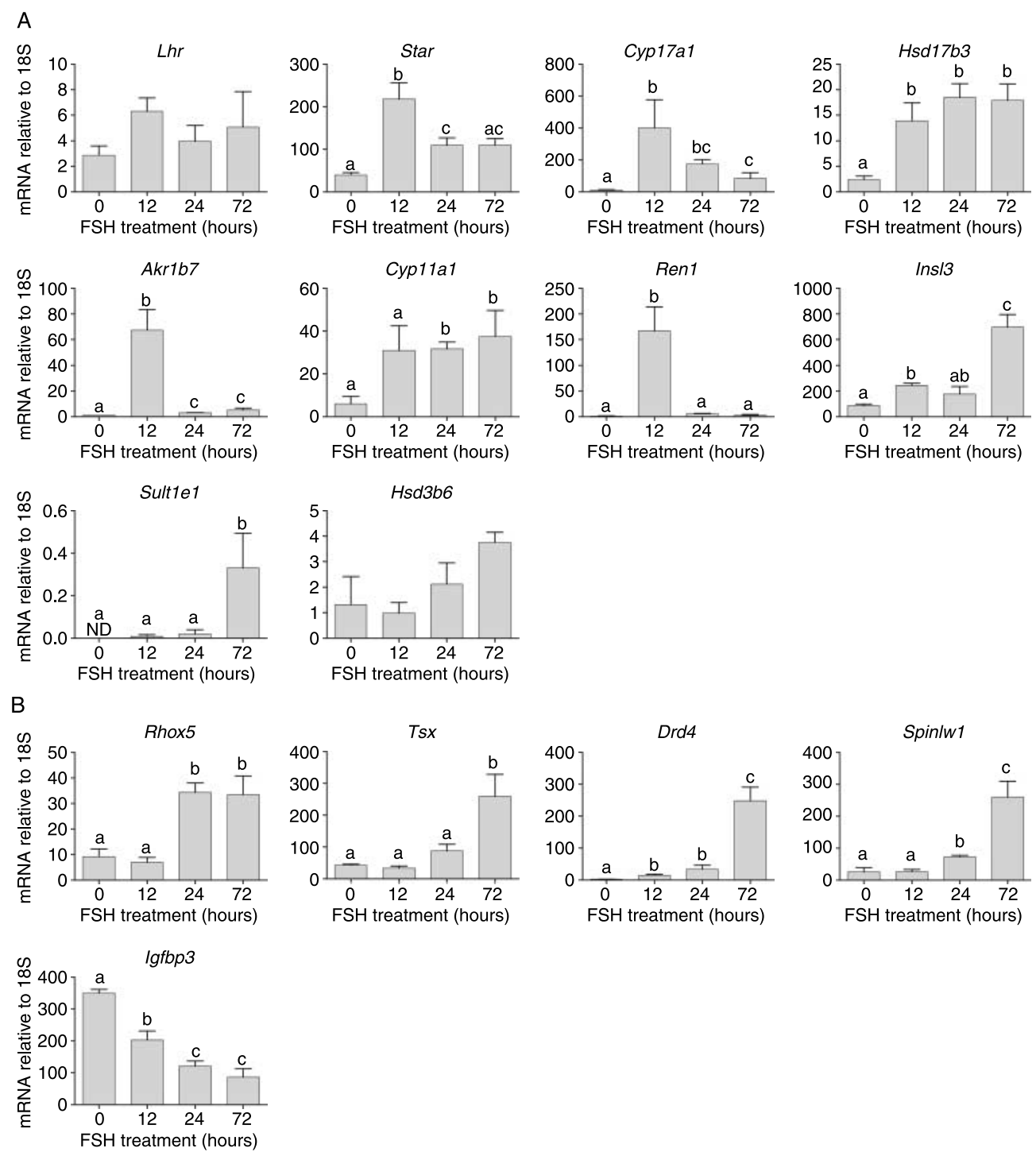

Figure 2 Real-time PCR measurements of mRNA transcript levels in testes from adult hpg mice treated for 0 (control), 12, 24 or $72 \mathrm{~h}$ with FSH. Data show results from Leydig cell-specific transcripts (A) and from Sertoli cell-specific, androgen-dependent transcripts (B). The mean \pm S.E.M. of three or four animals per group is shown. Groups with different letter superscripts are significantly different.

\section{Other transcripts}

Results from the array studies identified a number of transcripts regulated by FSH but without known function and/or known expression pattern in the testis. Levels of three of these transcripts (Wif1, Dmkn, Dkk3) were measured in $h p g$ testes after FSH treatment (Fig. 5). In all cases, FSH caused a significant increase in transcript levels confirming the results of the array study.

\section{Canonical pathway analysis}

Analysis of canonical pathways showed that components of the cholesterol biosynthetic pathway were significantly increased at $12 \mathrm{~h}$ but not at other times
(Supplementary Table 3A, see supplementary data in the online version of the Journal of Molecular Endocrinology at http://jme.endocrinology-journals. org/content/vol42/issue 4/) and that there was a general decline in transcripts encoding factors involved in formation and regulation of tight junctions (Supplementary Table 3B).

\section{Discussion}

FSH is essential for optimum fertility in the adult male but uncertainty remains about how it acts to regulate Sertoli cell activity and spermatogenesis. The $h p g$ mouse 

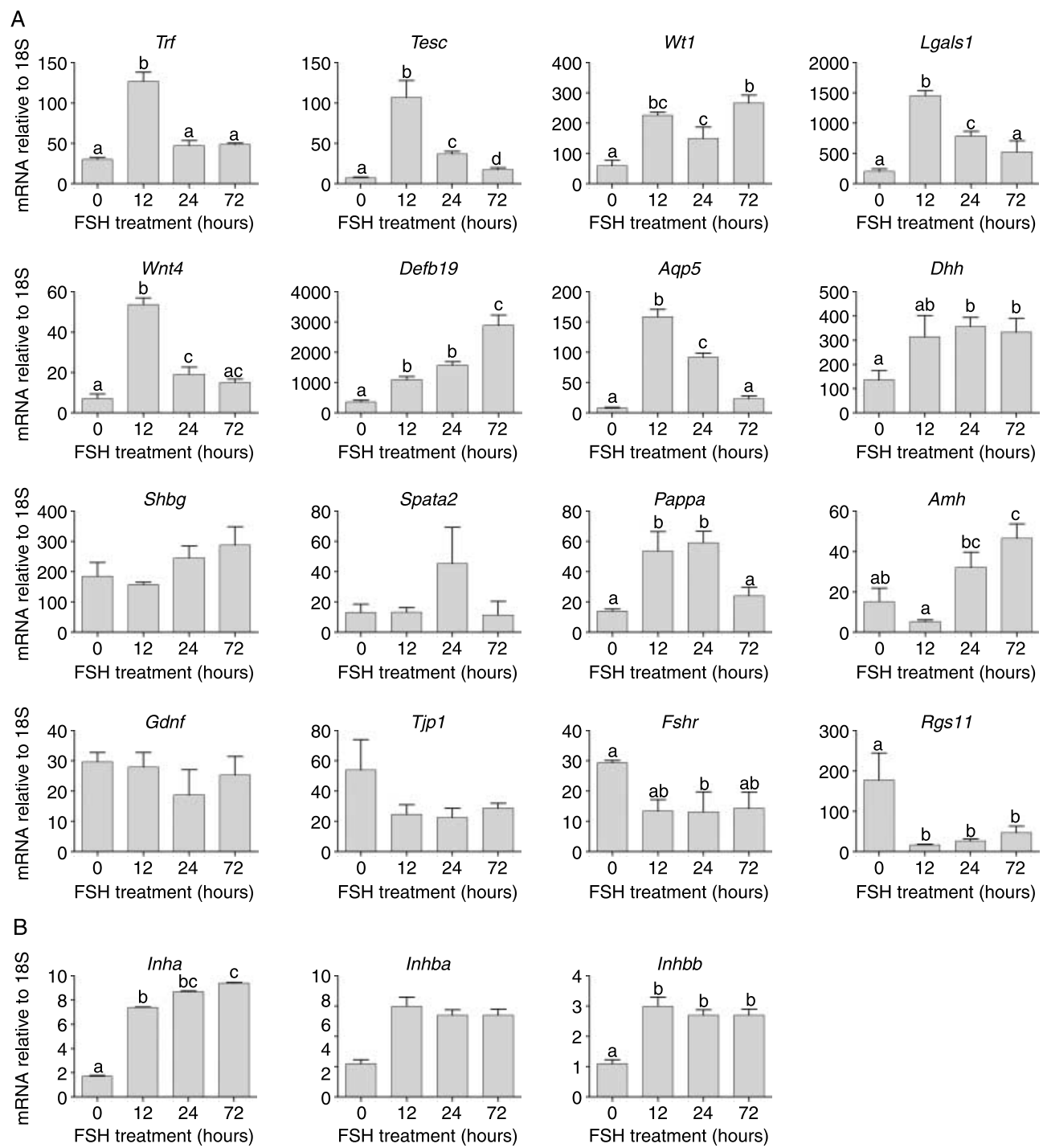

Figure 3 Real-time PCR measurements of Sertoli cell-specific mRNA transcript levels in testes from adult hpg mice treated for 0 (control), 12, 24 or $72 \mathrm{~h}$ with FSH. Results show the mean \pm s.E.M. of three or four animals per group. Groups with different letter superscripts are significantly different; where no superscripts are shown there was no difference between groups.

is an excellent model system with which to test the effects of FSH since the Sertoli cells have not been exposed to the hormone but express FSHR and are sensitive to FSH action. This study is an extension of earlier work by Sadate-Ngatchou et al. (2004) using a longer treatment period, different array chips with a larger characterised gene set (MOE430A chips (14 000 characterised genes) versus MG U74Av2 chips (6000 characterised genes, $6500 \mathrm{ESTs}$ )), a significantly larger animal cohort and recombinant FSH. In addition, the purpose of this study was to follow changes in testicular transcript levels in the $h p g$ in response to maintained levels of FSH rather than the acute response to a single administration. Together, the two studies complement each other and serve to identify transcripts regulated by FSH over the short and medium term. Interestingly, at $12 \mathrm{~h}$ after the start of FSH administration, when both studies can be directly compared with a degree of caution, there were only 44 differentially transcripts common to both studies, 25 up-regulated (e.g. Cyp17, Ren 1, Fos, Hdc, Col4a1) and 19 down-regulated (e.g. Rgs11, Cdo1, Erbb3, Ptk2b, Vnn1). This low number of transcripts in common may be due to a combination of the chips used, the age of the animals, the number of animals used and the treatment regime.

In this study, the total number of transcripts altered at each time point did not vary markedly across the treatment period but only 39 transcripts were 

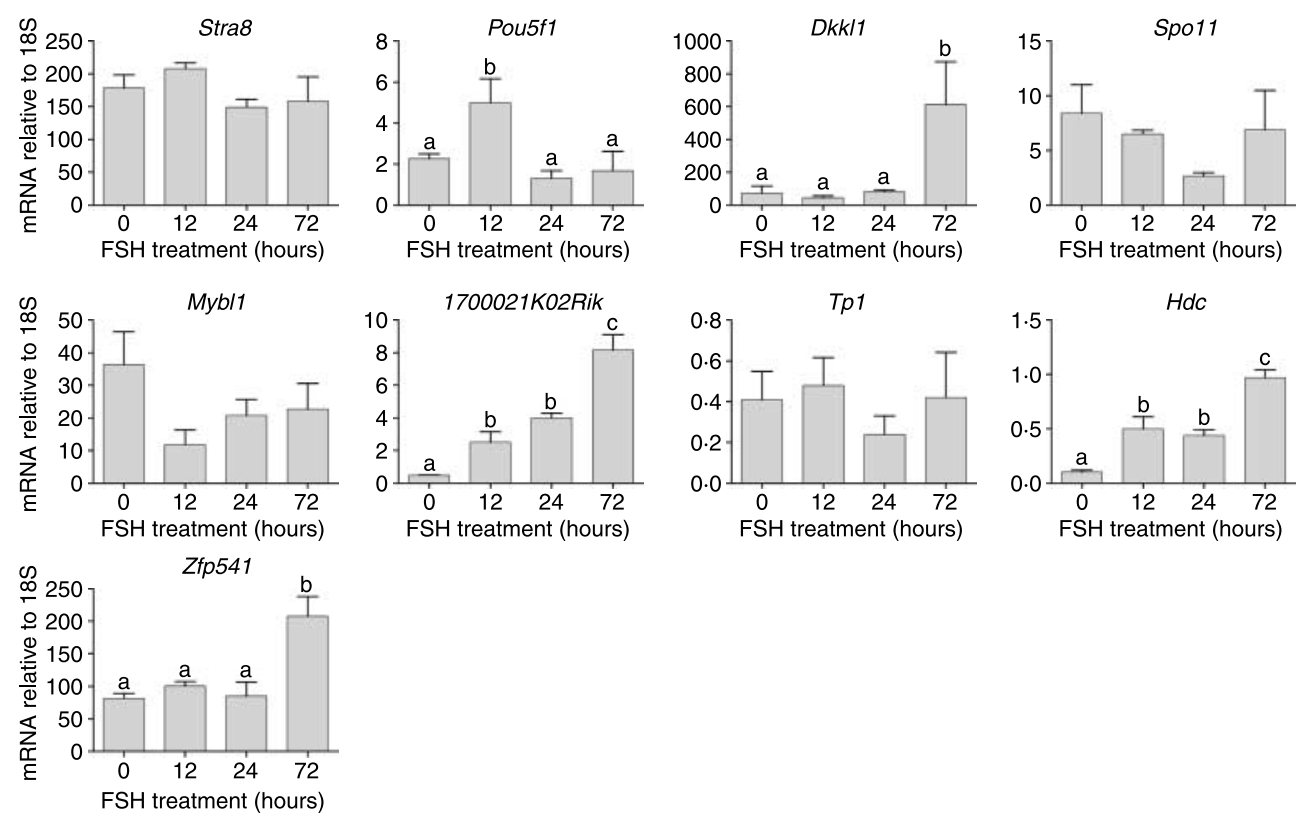

Figure 4 Real-time PCR measurements of germ cell-specific mRNA transcript levels in testes from adult hpg mice treated for 0 (control), 12, 24 or $72 \mathrm{~h}$ with FSH. Results show the mean \pm S.E.M. of three or four animals per group. Groups with different letter superscripts are significantly different; where no superscripts are shown there was no difference between groups.

up-regulated more than twofold at all times indicating that there was a changing pattern of expression as the exposure to FSH was maintained. There were also 63 transcripts down-regulated more than twofold at all times suggesting that the inhibitory effects of FSH are more consistent. Results from the arrays and from realtime PCR showed that FSH treatment caused a general increase in many transcripts encoding known Sertoli cell-specific products such as Tesc, Lgals1, Fabp5 and Aqp5 (Kingma et al. 1998, Perera et al. 2001, Dettin et al. 2003) although some transcripts (e.g. Shbg, Tjp1 (Wang et al. 1989, Byers et al. 1991)) were unaffected while others were decreased (see below) indicating that the effect of FSH was not simply to increase the overall activity of the cells. Comparison of the up-regulated transcripts in this study with the list of Sertoli cell transcripts generated by Chalmel et al. (2007) confirms that, at least initially, a high proportion of the affected transcripts are likely to be of Sertoli cell origin. The declining proportion of Sertoli cell transcripts at later times is likely to be due to increasing activity in other cells such as the Leydig cell. The lower proportion of down-regulated transcripts that match to the Sertoli cell list of Chalmel et al. (2007) may reflect the GeneChip sensitivity involved in generating that list since many of these down-regulated transcripts might be expected to have a low level of expression in the normal animal.

Among the transcripts that showed decreased levels in response to FSH were a number encoding tight junction components. This is consistent with a recent
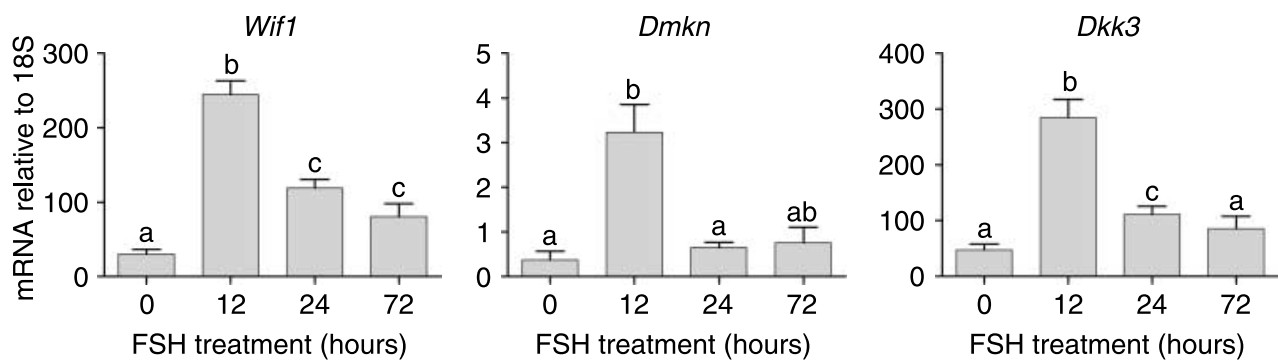

Figure 5 Real-time PCR measurements of mRNA transcript levels of species with unknown testicular origin. Levels were measured in testes from adult $h p g$ mice treated for 0 (control), 12, 24 or $72 \mathrm{~h}$ with FSH. Results show the mean \pm S.E.M. of three or four animals per group. Groups with different letter superscripts are significantly different. 
study which reported that gonadotrophins reduce transcript levels of Sertoli cell barrier components but that FSH may act at the level of protein organisation to induce barrier functionality (Tarulli et al. 2008). Other transcripts that showed a significant decrease in levels after FSH treatment included Fshr and Rgs11. It is well established that FSH will cause downregulation of its receptor by decreasing transcript levels (O'Shaughnessy 1980, Themmen et al. 1991) and a reduction in Fshr is to be expected. RGS11, in contrast, belongs to the regulator of $G$ protein-signalling family which are GTPase-activating proteins that act to inhibit signal transduction and thus play a role in desensitisation (Chasse \& Dohlman 2003). The role of RGSs in normal hormonal signalling is not well established but the declining levels of Rgs11 after FSH treatment may act to enhance signal transduction despite a reduction in receptor levels.

In addition to changes in Sertoli cell transcripts induced by FSH, it was clear from the rise in testicular androgen and the array and real-time PCR data that FSH was also acting to induce Leydig cell function. This effect was marked and rapid with a Leydig cell transcript (Ren1) showing the greatest fold change at $12 \mathrm{~h}$ (Deschepper et al. 1986). Results from the arrays and real-time PCR show that all components of the androgen biosynthetic pathway were induced at $12 \mathrm{~h}$ apart from Hsd3b6. Since Hsd3b1 is already highly expressed in the adult $h p g$ testis (Baker et al. 2003) lack of HSD3B6 is unlikely to affect the steroidogenic potential of the cells. In addition to the steroidogenic enzymes, pathway analysis showed that most components of the cholesterol biosynthetic pathway were induced $12 \mathrm{~h}$ after FSH treatment while $L d l r$ levels are increased. This shows that FSH is acting to increase the capacity of the Leydig cells to produce and sequester cholesterol and to convert cholesterol to androgen. Interestingly, one of the critical components of the cholesterol biosynthetic pathways (Mvk) also acts to inhibit Lhr translation (Nair \& Menon 2004) and this may serve to regulate further Leydig cell sensitivity to LH. The $h p g$ mouse testis is likely to contain both adult and fetal-type Leydig cells (Baker et al. 2003) and $H s d 3 b 6$ is a marker of adult Leydig cell differentiation (Baker et al. 1999). This might imply that FSH is acting to induce activity in the fetal Leydig cell population but Sult1e1 is a marker of adult Leydig cells (Song et al. 1997) and is increased $72 \mathrm{~h}$ after FSH suggesting that the effects of FSH are probably being mediated through the adult Leydig cells.

In the testis, receptors for FSH are only found in the Sertoli cells (Heckert \& Griswold 2002) and the effects of FSH must be mediated by a factor or factors released by the Sertoli cells which act on the Leydig cells. In the short-term, the effects of FSH on Leydig cell function in the $h p g$ appear to be more marked than effects of hCG
(Baker et al. 2003) and the effects are also very rapid since Sadate-Ngatchou et al. (2004) saw a marked increase in Cyp17a1 after only $4 \mathrm{~h}$ of FSH treatment. FSH appears, therefore, to be able to induce a powerful and rapid response in Leydig cells presumably through stimulation of release of potent trophic factors by the Sertoli cells. The presence of such factors has been postulated for a number of years since early studies on perfused testes or hypophysectomised animals treated with FSH (Johnson \& Ewing 1971, Chen et al. 1976, Vihko et al. 1991). One report has suggested that the active factors are TIMP1 and Procathepsin L (Boujrad et al. 1995) but this has not been confirmed and we saw no evidence of changes in these factors in our study. Following FSH treatment, our array data showed that there was an increase in Igfl levels and IGF1 has been suggested to play a role in Leydig cell differentiation (Morera et al. 1987). Interestingly, there was a marked decline in Igfbp3 and an increase in Pappa levels after FSH treatment. Increased Pappa would be expected to increase the bioavailability and activity of IGF1 (Conover et al. 2004) although the effect of altered Igfbp3 may be more complex (Modric et al. 2001). The time-course of changes in expression of Igfl levels does not appear to fit well with a role in the stimulation of Leydig cell function after FSH treatment although it is possible that early changes in Pappa and Igfbp3 may alter early IGF1 bioavailability. Other secreted molecules showing a marked increase in transcript levels after FSH include Wif1, Dkk3 and Dmkn. Both WIF1 and DKK3 act to regulate $\mathrm{WNT}$ signalling and the $\mathrm{WNT} / \mathrm{CTNNB} 1$ pathway is critical for normal Sertoli cell development (Boyer et al. 2008) although its function in the Leydig cell remains uncertain.

Following the increase in Leydig cell activity after FSH treatment, there was a significant change in the levels of known androgen-dependent Sertoli cellspecific transcripts. It is possible that changes in these transcripts are due to direct effects of FSH treatment but the known androgen-dependence of the transcripts makes it more likely that changes are related to increased Leydig cell androgen production induced by FSH. The rise in intratesticular androgen after FSH treatment was significant but levels remained very low, probably because FSH stimulates synthesis of the components of the steroidogenic pathway without being able to stimulate the pathway itself. The apparent effect of these low levels of androgen on Sertoli cell transcript levels suggests that the Sertoli cells are extremely sensitive to androgen stimulation.

Treatment of $h p g$ mice with FSH increased vacuolation in the Sertoli cells and induced formation of a lumen within the seminiferous tubules but had little apparent effect on germ cell morphology or progression up to $72 \mathrm{~h}$. Changes in the Sertoli cell and tubule diameter correlate with a marked rise in $A q p 5$ at 
$12 \mathrm{~h}$ suggesting that increased water movement across the Sertoli cell membrane may contribute to increased tubular diameter and testis weight. The absence of spermatogenic progression over the time-course studied is likely to reflect the inactive state of the Sertoli cell in the adult $h p g$ testis and the time required for the Sertoli cell to become active enough to support germ cell maturation. Real-time PCR studies of a small number of known germ cell genes showed that there was a variable response of germ cell transcripts to FSH stimulation. POU5F1 has been shown to be necessary for primordial germ cell survival (Kehler et al. 2004) and the increase in response to $\mathrm{FSH}$, albeit small, may facilitate an increase in spermatogonial number within the testis. DKKL1 and ZFP541 are expressed in both spermatocytes and spermatids (Kohn et al. 2005, Choi et al. 2008) while HDC and SPATIAL are associated with round spermatids and the later stages of spermatogenesis (Safina et al. 2002, Irla et al. 2003). Lack of a general increase in germ cell transcripts (data from both arrays and real-time PCR) would indicate that the effects seen are not due to an overall increase in germ cell number but are more likely to be part of an early specific response to FSH stimulation. It has been shown previously that more prolonged treatment of $h p g$ mice with FSH will stimulate an increase in germ cell number and development (O'Shaughnessy et al. 1992, Singh \& Handelsman 1996b, Baines et al. 2008) but the stimulatory effect of FSH on the Leydig cells makes interpretation of the FSH effects on the germ cells difficult because of the known stimulatory effect of testosterone on germ cell development in the $h p g$ mouse (O'Shaughnessy \& Sheffield 1990, Singh et al. 1995).

In this study, FSH treatment of $h p g$ mice for up to $72 \mathrm{~h}$ induced significant changes in Sertoli cell transcript levels and led to indirect stimulation of Leydig cell function. The changes in Leydig cell activity probably induced further changes in androgen-dependent Sertoli cell transcripts. While FSH is known to be required for optimal germ cell development (Abel et al. 2000, 2008), treatment of $h p g$ mice for $72 \mathrm{~h}$ did not have a marked effect on germ cell differentiation suggesting that longer-term action of FSH is required to induce germ cell proliferation and progression.

\section{Declaration of interest}

The authors declare that there is no conflict of interest that could be perceived as prejudicing the impartiality of the research reported.

\section{Funding}

This study was supported by the Wellcome Trust (grant number 078137).

\section{Acknowledgements}

We would like to thank Ana Monteiro for technical assistance, Mohan Masih for histology and animal care staff for assistance with this project. Sheena Lee is supported by the Wellcome Trust funded OXION initiative.

\section{References}

Abel MH, Wootton AN, Wilkins V, Huhtaniemi I, Knight PG \& Charlton HM 2000 The effect of a null mutation in the folliclestimulating hormone receptor gene on mouse reproduction. Endocrinology 141 1795-1803.

Abel MH, Baker PJ, Charlton HM, Monteiro A, Verhoeven G, De Gendt K, Guillou F \& O'Shaughnessy PJ 2008 Spermatogenesis and Sertoli cell activity in mice lacking Sertoli cell receptors for follicle stimulating hormone and androgen. Endocrinology 149 3279-3285.

Baban D \& Davies KE 2008 Microarray analysis of mdx mice expressing high levels of utrophin: therapeutic implications for dystrophin deficiency. Neuromuscular Disorders 18 239-247.

Baines H, Nwagwu MO, Hastie GR, Wiles RA, Mayhew TM \& Ebling FJ 2008 Effects of estradiol and FSH on maturation of the testis in the hypogonadal (hpg) mouse. Reproductive Biology and Endocrinology 64.

Baker PJ, Sha JA, McBride MW, Peng L, Payne AH \& O'Shaughnessy PJ 1999 Expression of 3beta-hydroxysteroid dehydrogenase type I and VI isoforms in the mouse testis during development. European Journal of Biochemistry 260 911-916.

Baker PJ, Johnston H, Abel MH, Charlton HM \& O'Shaughnessy PJ 2003 Differentiation of adult-type Leydig cells occurs in gonadotrophin-deficient mice. Reproductive Biology and Endocrinology 14.

Barakat B, O'Connor A, Gold E, de Kretser D \& Loveland K 2008 Inhibin, activin, follistatin and follicle stimulating hormone serum levels and testicular production are highly modulated during the first spermatogenic wave in mice. Reproduction 136 345-359.

Baron S, Manin M, Aigueperse C, Berger M, Jean C, Veyssiere G \& Morel L 2003 Hormonal and developmental regulation of the mouse aldose reductase-like gene akr $1 b 7$ expression in Leydig cells. Journal of Molecular Endocrinology 31 71-81.

Boujrad N, Ogwuegbu SO, Garnier M, Lee CH, Martin BM \& Papadopoulos V 1995 Identification of a stimulator of steroidhormone synthesis isolated from testis. Science 268 1609-1612.

Boyer A, Hermo L, Paquet M, Robaire B \& Boerboom D 2008 Seminiferous tubule degeneration and infertility in mice with sustained activation of WNT/CTNNB1 signaling in Sertoli cells. Biology of Reproduction 79 475-485.

Byers S, Graham R, Dai HN \& Hoxter B 1991 Development of Sertoli cell junctional specializations and the distribution of the tightjunction-associated protein ZO-1 in the mouse testis. American Journal of Anatomy 191 35-47.

Cattanach BM, Iddon CA, Charlton HM, Chiappa SA \& Fink G 1977 Gonadtrophin releasing hormone deficiency in a mutant mouse with hypogonadism. Nature 269 338-340.

Chalmel F, Rolland AD, Niederhauser-Wiederkehr C, Chung SS, Demougin P, Gattiker A, Moore J, Patard JJ, Wolgemuth DJ, Jégou B et al. 2007 The conserved transcriptome in human and rodent male gametogenesis. PNAS 104 8346-8351.

Charlton HM, Halpin DMG, Iddon CA, Rosie R, Levy G, McDowell IFW, Megson A, Morris JF, Bramwell A, Speight A et al. 1983 The effects of daily administration of single and multiple injections of gonadotrophin-releasing hormone on pituitary and gonadal function in the hypogonadal (hpg) mouse. Endocrinology 113 $535-544$. 
Chasse SA \& Dohlman HG 2003 RGS proteins: G protein-coupled receptors meet their match. Assay and Drug Development Technologies 1 357-364.

Chen JK \& Heckert LL 2001 Dmrt1 expression is regulated by folliclestimulating hormone and phorbol esters in postnatal Sertoli cells. Endocrinology 142 1167-1178.

Chen YI, Payne AH \& Kelch RP 1976 FSH stimulation of Leydig cell function in the hypophysectomized immature rat. Proceedings of the Society for Experimental Biology and Medicine 153 473-475.

Choi E, Han C, Park I, Lee B, Jin S, Choi H, Kim DH, Park ZY, Eddy EM \& Cho C 2008 A novel germ cell-specific protein, SHIP1, forms a complex with chromatin remodeling activity during spermatogenesis. Journal of Biological Chemistry 283 35283-35294.

Conover CA, Bale LK, Overgaard MT, Johnstone EW, Laursen UH, Fuchtbauer EM, Oxvig C \& van Deursen J 2004 Metalloproteinase pregnancy-associated plasma protein A is a critical growth regulatory factor during fetal development. Development 131 $1187-1194$

Cunningham DB, Segretain D, Arnaud D, Rogner UC \& Avner P 1998 The mouse Tsx gene is expressed in Sertoli cells of the adult testis and transiently in premeiotic germ cells during puberty. Developmental Biology 204 345-360.

Czechowski T, Bari RP, Stitt M, Scheible WR \& Udvardi MK 2004 Realtime RT-PCR profiling of over 1400 Arabidopsis transcription factors: unprecedented sensitivity reveals novel root- and shootspecific genes. Plant Journal 38 366-379.

Denolet E, De Gendt K, Allemeersch J, Engelen K, Marchal K, Van Hummelen P, Tan KA, Sharpe RM, Saunders PT, Swinnen JV et al. 2006 The effect of a Sertoli cell-selective knockout of the androgen receptor on testicular gene expression in prepubertal mice. Molecular Endocrinology 20 321-334.

Deschepper CF, Mellon SH, Cumin F, Baxter JD \& Ganong WF 1986 Analysis by immunocytochemistry and in situ hybridization of renin and its mRNA in kidney, testis, adrenal, and pituitary of the rat. PNAS 83 7552-7556.

Dettin L, Rubinstein N, Aoki A, Rabinovich GA \& Maldonado CA 2003 Regulated expression and ultrastructural localization of galectin-1, a proapoptotic beta-galactoside-binding lectin, during spermatogenesis in rat testis. Biology of Reproduction 68 51-59.

Dierich A, Sairam MR, Monaco L, Fimia GM, Gansmuller A, LeMeur M \& Sassone-Corsi P 1998 Impairing follicle-stimulating hormone (FSH) signaling in vivo: targeted disruption of the FSH receptor leads to aberrant gametogenesis and hormonal imbalance. PNAS 95 13612-13617.

De Gendt K, Swinnen JV, Saunders PT, Schoonjans L, Dewerchin M, Devos A, Tan K, Atanassova N, Claessens F, Lecureuil C et al. 2004 A Sertoli cell-selective knockout of the androgen receptor causes spermatogenic arrest in meiosis. PNAS 101 1327-1332.

Le Goascogne C, Sananes N, Gouezou M, Takemori S, Kominami S, Baulieu EE \& Robel P 1991 Immunoreactive cytochrome P450 (17alpha) in rat and guinea-pig gonads, adrenal-glands and brain. Journal of Reproduction and Fertility 93 609-622.

Haywood M, Spaliviero J, Jimemez M, King NJ, Handelsman DJ \& Allan CM 2003 Sertoli and germ cell development in hypogonadal (hpg) mice expressing transgenic follicle-stimulating hormone alone or in combination with testosterone. Endocrinology 144 509-517.

Heckert LL \& Griswold MD 2002 The expression of the folliclestimulating hormone receptor in spermatogenesis. Recent Progress in Hormone Research 57 129-148.

Hirst RC, Abel MH, Wilkins V, Simpson C, Knight PG, Zhang FP, Huhtaniemi I, Kumar TR \& Charlton HM 2004 Influence of mutations affecting gonadotropin production or responsiveness on expression of inhibin subunit mRNA and protein in the mouse ovary. Reproduction 128 43-52.

Irla M, Puthier D, Le Goffic R, Victorero G, Freeman T, Naquet P, Samson M \& Nguyen C 2003 Spatial, a new nuclear factor tightly regulated during mouse spermatogenesis. Gene Expression Patterns 3 $135-138$.
Jiang Y, Oliver P, Davies KE \& Platt N 2006 Identification and characterization of murine SCARA5, a novel class A scavenger receptor that is expressed by populations of epithelial cells. Journal of Biological Chemistry 281 11834-11845.

Johnson BH \& Ewing LL 1971 Follicle-stimulating hormone and the regulation of testosterone secretion in rabbit testes. Science $\mathbf{1 7 3}$ 635-637.

Kehler J, Tolkunova E, Koschorz B, Pesce M, Gentile L, Boiani M, Lomeli H, Nagy A, McLaughlin KJ, Scholer HR et al. 2004 Oct4 is required for primordial germ cell survival. EMBO Reports $\mathbf{5}$ 1078-1083.

Kingma PB, Bok D \& Ong DE 1998 Bovine epidermal fatty acid-binding protein: determination of ligand specificity and cellular localization in retina and testis. Biochemistry 37 3250-3257.

Kohn MJ, Kaneko KJ \& DePamphilis ML 2005 DkkL1 (Soggy), a Dickkopf family member, localizes to the acrosome during mammalian spermatogenesis. Molecular Reproduction and Development 71 516-522.

Krishnamurthy H, Babu PS, Morales CR \& Sairam MR 2001 Delay in sexual maturity of the follicle-stimulating hormone receptor knockout male mouse. Biology of Reproduction 65 522-531.

Kumar TR, Wang Y, Lu N \& Matzuk MM 1997 Follicle stimulating hormone is required for ovarian follicle maturation but not male fertility. Nature Genetics 15 201-204.

Lang J 1995 Assay for deletion in GnRH (hpg) locus using PCR. Mouse Genome 89857.

Lindsey JS \& Wilkinson MF 1996 Pem: a testosterone-regulated and LH-regulated homeobox gene expressed in mouse sertoli cells and epididymis. Developmental Biology 179 471-484.

Mason AJ, Hayflick JS, Zoeller RT, Young WS, Phillips HS, Nikolics K \& Seeburg TA 1986 A deletion truncating the GnRH gene is responsible for hypogonadism in the hpg mouse. Science $\mathbf{2 3 4}$ 1366-1371.

McLachlan RI, O'Donnell L, Meachem SJ, Stanton PG, de Kretser DM, Pratis K \& Robertson DM 2002 Identification of specific sites of hormonal regulation in spermatogenesis in rats, monkeys, and man. Recent Progress in Hormone Research 57 149-179.

Modric T, Silha JV, Shi Z, Gui Y, Suwanichkul A, Durham SK, Powell DR \& Murphy LJ 2001 Phenotypic manifestations of insulin-like growth factor-binding protein-3 overexpression in transgenic mice. Endocrinology 142 1958-1967.

Monaco L, Foulkes NS \& Sassone-Corsi P 1995 Pituitary folliclestimulating hormone (FSH) induces CREM gene expression in Sertoli cells: involvement in long-term desensitization of the FSH receptor. PNAS 92 10673-10677.

Morera AM, Chauvin MA, De Peretti E, Binoux M \& Benahmed M 1987 Somatomedin C/insulin-like growth factor 1: an intratesticular differentiative factor of Leydig cells? Hormone Research 28 $50-57$.

Morris PL, Vale WW, Cappel S \& Bardin CW 1988 Inhibin production by primary Sertoli cell-enriched cultures: regulation by folliclestimulating hormone, androgens, and epidermal growth factor. Endocrinology 122 717-725.

Myers M, Ebling FJ, Nwagwu M, Boulton R, Wadhwa K, Stewart J \& Kerr JB 2005 Atypical development of Sertoli cells and impairment of spermatogenesis in the hypogonadal (hpg) mouse. Journal of Anatomy 207 797-811.

Nair AK \& Menon KMJ 2004 Isolation and characterization of a novel trans-factor for luteinizing hormone receptor mRNA from ovary. Journal of Biological Chemistry 279 14937-14944.

O'Shaughnessy PJ 1980 FSH receptor autoregulation and cyclic AMP production in the immature rat testis. Biology of Reproduction $\mathbf{2 3}$ 810-814.

O'Shaughnessy PJ \& Sheffield JW 1990 Effect of testosterone on testicular steroidogenesis in the hypogonadal (hpg) mouse. Journal of Steroid Biochemistry 35 729-734. 
O’Shaughnessy PJ, Bennett MK, Scott IS \& Charlton HM 1992 Effects of FSH on Leydig cell morphology and function in the hypogonadal mouse. Journal of Endocrinology 135 517-525.

O'Shaughnessy PJ, Willerton L \& Baker PJ 2002 Changes in Leydig cell gene expression during development in the mouse. Biology of Reproduction 66 966-975.

O'Shaughnessy PJ, Abel M, Charlton HM, Hu B, Johnston H \& Baker PJ 2007 Altered expression of genes involved in regulation of vitamin A metabolism, solute transportation, and cytoskeletal function in the androgen-insensitive tfm mouse testis. Endocrinology 148 2914-2924.

Perera EM, Martin H, Seeherunvong T, Kos L, Hughes IA, Hawkins JR \& Berkovitz GD 2001 Tescalcin, a novel gene encoding a putative EF-hand $\mathrm{Ca}(2+)$-binding protein, Col9a3, and renin are expressed in the mouse testis during the early stages of gonadal differentiation. Endocrinology 142 455-463.

Sadate-Ngatchou PI, Pouchnik DJ \& Griswold MD 2004 Folliclestimulating hormone induced changes in gene expression of murine testis. Molecular Endocrinology 18 2805-2816.

Safina F, Tanaka S, Inagaki M, Tsuboi K, Sugimoto Y \& Ichikawa A 2002 Expression of L-histidine decarboxylase in mouse male germ cells. Journal of Biological Chemistry 277 14211-14215.

Singh J \& Handelsman DJ $1996 a$ Neonatal administration of FSH increases Sertoli cell numbers and spermatogenesis in gonadotropin-deficient (hpg) mice. Journal of Endocrinology 151 $37-48$.

Singh J \& Handelsman DJ $1996 b$ The effects of recombinant FSH on testosterone-induced spermatogenesis in gonadotropin-deficient (Hpg) mice. Journal of Andrology 17 382-393.

Singh J, O'Neill C \& Handelsman DJ 1995 Induction of spermatogenesis by androgens in gonadotropin-deficient (Hpg) mice. Endocrinology 136 5311-5321.

Skinner MK, Schlitz SM \& Anthony CT 1989 Regulation of Sertoli cell differentiated function: testicular transferrin and androgen-binding protein expression. Endocrinology 124 3015-3024.

Smith EP, Dickson BA \& Chernausek SD 1990 Insulin-like growth factor binding protein-3 secretion from cultured rat sertoli cells: dual regulation by follicle stimulating hormone and insulin-like growth factor-I. Endocrinology 127 2744-2751.

Song WC, Qian Y, Sun X \& Negishi M 1997 Cellular localization and regulation of expression of testicular estrogen sulfotransferase. Endocrinology 138 5006-5012.

Song KH, Park JI, Lee MO, Soh J, Lee K \& Choi HS 2001 LH induces orphan nuclear receptor Nur77 gene expression in testicular Leydig cells. Endocrinology 142 5116-5123.

Tarulli GA, Meachem SJ, Schlatt S \& Stanton PG 2008 Regulation of testicular tight junctions by gonadotrophins in the adult Djungarian hamster in vivo. Reproduction 135 867-877.

Themmen AP, Blok LJ, Post M, Baarends WM, Hoogerbrugge JW, Parmentier M, Vassart G \& Grootegoed JA 1991 Follitropin receptor down-regulation involves a cAMP-dependent post-transcriptional decrease of receptor mRNA expression. Molecular and Cellular Endocrinology 78 R7-R13.

Verhoeven G \& Cailleau J 1988 Follicle-stimulating hormone and androgens increase the concentration of the androgen receptor in Sertoli cells. Endocrinology 122 1541-1550.

Vihko KK, Lapolt PS, Nishimori K \& Hsueh AJ 1991 Stimulatory effects of recombinant follicle-stimulating hormone on Leydig cell function and spermatogenesis in immature hypophysectomized rats. Endocrinology 129 1926-1932.

Wang Y-M, Sullivan PM, Petrusz P, Yarbrough W \& Joseph DR 1989 The androgen-binding protein gene is expressed in CD1 mouse testis. Molecular and Cellular Endocrinology 63 85-92.

Wreford NG, Rajendra Kumar T, Matzuk MM \& de Kretser DM 2001 Analysis of the testicular phenotype of the follicle-stimulating hormone beta-subunit knockout and the activin type II receptor knockout mice by stereological analysis. Endocrinology 142 2916-2920.

Received in final form 5 January 2009

Accepted 9 January 2009

Made available online as an Accepted Preprint 9 January 2009 